\title{
ANALISIS GAMBAR ILUSTRASI HOMBO BATU NIAS GUNUNGSITOLI
}

\author{
Wahana E. S. Halawa ${ }^{1 *}$, R. Triyanto ${ }^{2 *}$, Dwi Budiwiwaramulja ${ }^{3 *}$, Adek Cerah Kurnia Azis ${ }^{4^{*}}$ \\ Program Studi Pendidikan Seni Rupa Jurusan Seni Rupa Fakultas Bahasa dan Seni \\ Universitas Negeri Medan \\ Jl. Willem Iskandar Pasar V Medan Estate, Kec, Percut Sei Tuan, Kab. Deli Serdang, Kode Pos 20371 \\ Sumatera Utara. Indonesia \\ Email:wahanahalawa@yahoo.com
}

\begin{abstract}
Abstrak
Penelitian ini bertujuan untuk meng analis is hasil karya menggambar ilustrasi hombo batu Nias dengan teknik arsir ditinjau dari komposisi, Proporsi dan gelap terang karya siswa kelas VIII SMP Negeri 1 Gunungstitoli Utara. Metode yang digunakan dalam penelitian ini adalah kualitatif yang bersifat deskriptif. Populasi dalam penelitian ini adalah seluruh karya siswa kelas VIII SMP Negeri 1 Gunung sitoli Utara dengan jumlah 144 karya dan sampel penelitian yaitu kelas VIII-A yang berjumlah 29 karya dengan menggunakan teknik Cluster Random Sampling. Hasil penelitian menunjukkan bahwa analisis kary a mengg ambar ilus trasi hombo batu Nias sis wa kelas VIII-A SMP Negeri 1 Gunungsitoli Utara rata-rata mendapatkan kategori Cukup dengan total 25 Karya, sedangkan mendapatkan kategori Baik total 2 karya. Dan 2 karya siswa pada kategori Kurang. Pada hasil rekapitulasinilai karya gambar ilus trasi hombo batu Nias indikator Komposisi mendapatkan kategori Cukup dengan nilai rata-rata 78,9. Indikator Proporsi mendapatkan kategori Cukup dengan nilai rata-rata 78,6. Dan indikator Gelap-terang mendapatkan kategori Cukup deng an hasil nilai rata-rata 79,9. Deng an demikian kelemahan hasil karya sis wa kelas VIII-A SMP Negeri 1 Gunungsitoli Utara terletak pada indikator Proporsi, dan dari 29 karya sis wa y ang menonjol adalah indikator Gelap Terang. Selanjutny anilai terttinggi pada karya siswa dengan mendapatkan nilai rata-rata 86 padakary a nomor 23 . Sed angkan nilai terendah padakarya siswa dengan hasil nilai rata-rata 74 pada karya nomor 28.Berdasarkan hasil analisis data diperoleh kesimpulan bahwa hasil karya gambar ilustrasi hombo batu Nias SMP Negeri 1 Gunungsitoli Utara dikatakan cukup baik, karena terdapat kelemahan penerapan indikator proporsi, namun nilai lebih pada indikator Komposisi dan Gelap Terang.
\end{abstract}

Kata Kunci: hombo batu nias.

\begin{abstract}
This study aims to analyze the work of drawing illustrations of Nias stone hombo with shading techniques in terms of composition, proportion and darkness of the work of eighth grade students of SMP Negeri 1 Gunungstitoli Utara. The method used in this research is descriptive qualitative. The population in this study were all students of class VIII of SMP Negeri 1 Gunungsitoli Utara with a total of 144 works and the study sample was class VIII-A, amounting to 29 works using the Cluster Random Sampling technique. The results showed that the analysis of works drawing illustrations of Nia s stone hombo class VIII-A students at SMPNegeri 1 Gunungsitoli Utara on average received the category of Enough with a total of 25 works, while getting the Good category a total of 2 works. And 2 students' work in the Less category. In the recapitulation of the value of the Nias stone hombo illustration illustration, the Composition indicator getsthe Fair category with an average value of 78.9. Proportion Indicators get the Fair category with an average value of 78.6. And the Dark-light indicator gets the Fair category with an average score of 79.9. Thus the weaknesses of the work of VIII-A students of SMP Negeri 1 Gunungsitoli Utara are in the Proportion indicator, and of the 29 outstanding student works are Dark Light indicators. Furthermore, the highest value in the work of students by getting an average value of 86 in the work number 23 . While the lowest value in the work of studentswith an average value of 74 in the work number 28. Based on the results of data analysis, it was concluded that the results of the Nias hombo illustration illustration works SMP Negeri 1 Gunungsitoli Utara is said to be quite good, because there are weaknesses in the application of the proportion indicator, but more value in the composition of the Dark and Composition indicator.
\end{abstract}

Keywords: hombo batunias. 


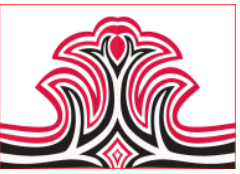

PENDAHULUAN

Kegiatan belajar meng ajar adalah proses penyampaian ilmu atau tranformasi ilmu yang dilakukan oleh tenaga pendidik kepada peserta didik. Secara umum kegiatan belajar mengajar pada dasarnya bertujuan untuk melatih kemampuan atau kompetensi yang mengarah pada ranah pengetahuan, keterampilan dan sikap siswa. Demikian juga dalam pembelajaran menggambar ilustrasi. Guru perlu memfasilitasi yang memungkinkan seluruh potensi sis wa dapat berpikir, berketarampilan dan bersikap melalui kegiatan belajar di kelas maupun di luar kelas.

Salah satu materi pembelajaran Seni Rupa yang terdapat pada kurikulum SMP kelas VIII yaitu menggambar ilustrasi. Menggambar ilustrasi juga merupakan wadah untuk menuangkan ide dan kemampuan imajinasi dengan menerangkan sebuah cerita ke dalambahas a vis ual. Meng gambar bagi siswa harus diberikan bukan untuk kegiatan seni semata, tetapi lebih jauh untuk mempertajam pengamatan dalam mengolah rasa. Pelajaran menggambar ilustrasi mempunyai landas an sebagai cara melatih seseorang dalam menuangkan bentuk dan pola yang ada di alam yang bertuuan untuk menerangkan, sekaligus melatih keseimbangan dan keserasian antara pikiran, perasaan dan gerakan motorik.

Setelah melakukan observasi dan pengamatan di SMP Negeri 1 Gunungsitoli Utara dengan bahasan pokok menggambar ilustrasi kebudayaan daerah, beberapa hasil kary a sis wa terdapat kelemahan seperti penerapan komposisi, proporsi dan gelap terang dalam menggambar. Sis wa masih ragu ketika menekan pensil untuk mengarsir, sehingga karya siswa kurang tepat dalam menghasilkan karya gambar yang baik, maka karya sis wa SMP Negeri 1 Gunungsitoli Utara kurang memuaskan. Karya siswa belums esuai dengan prinsipprinsip seni dalam menggambar ilustrasi. Oleh karena itu pada pembelajaran menggambar ilustrasi, peneliti ingin menganalisis hasil dari pada karya gambar ilustrasi dengan teknik arsir bertemakan Hombo Batu karya siswa kelas VIII SMP Negeri 1 Gunungsitoli Utara ditinjau dari komposisi, proporsi dan gelap terang.

\section{KAJIAN TEORI}

\section{Pengertian Analisis}

Bogdan dan Bikken mengatakan "Analis is data adalah proses pencarian dan pengaturan secarasistematik hasil wanwancara, catatan-catatan, dan bahan-bahan yang dikumpulkan untuk meningkatkan pemahaman terhadap semua hal yang dikumpulkan dan memungkinkan menyajikan apa yang ditemukan"
Gorga : Jurnal Seni Rupa

Volume 09 Nomor 01 Januari-Juni 2020

p-ISSN: 2301-5942 | e-ISSN: 2580-2380

(Gunawan 2007:210). Pengertian analisis dalam penelitian kuantitatif, merupakan kegiatan setelah data dari seluruh responden atau sumber data lain terkumpul. (Sugiyono, 2014:207). Selanjutnya Furhan dalam Siregar (2020: 95) menjelaskan analisis adalah melihat kembali ulasan penelitian yang gunanya memeriksa rencana penyajian data dan analis is -statistik yang telah ditetapkan semula. Berdas arkan beberapa pendapat tersebut dapat disimpulkan bahwa analisis adalah penyelidikan yang menguraikan data dan mengelompokkan data tersebut.

\section{Pengertian Karya}

Karya seni adalah produk dari kegiatan manusia. Ini sesuai dengan pendapat John Hospers, yang meny atakan seni dalamartian y ang seluas-luasnya, seni meliputi setiap benda yang dibuat oleh manusia untuk dilawankan dengan benda-benda alamiah. (Surajiyo, 2007:109). Oleh Fiedler dikatakan "bahwa seniadalah berjuang untuk mengekspresikan hubungan manusia dengan alamsemesta. Alam, dengan segala materialnya (termasuk jasad manusia), telah menyelenggarakan berbagai sarana bagi pencetusan ide-ide kesenian sebagai bentuk ekspresi spritual. (Aesijah,2000:72). Berdasarkan pendapat di atas, maka pengertian karya adalah proses pembuatan sesuatu yang dapat menimbulkan rasa indah bagi orang yang melihat dan merasakannya.

\section{Pengertian Gambar}

Gambar merupakan bahasa yang universal dan telah berkembang sebelum ditemukannya bahasa tulisan. Menggambar merupakan wujud pengeksplorasian teknis dan gaya, penggalian gagasan dan kreativitas, bahkan bisa menjadi sebuah eks presi dan aktualisasi diri. (Apriyatno, 2013:6). Adapun pendapat lain "menggambar adalah salah satu bentuk komunikasi yang tercipta kepermukaan sebagai sebuah ekspresi, observasi, dan gambaran perasaan yang terdalam seorng artis maupun desainer". (Widyokusumo, 2014 : 910). Berdasarkan uraian di atas pengertian menggambar adalah suatu kegiatan atau proses dalam menciptakan karya visual seni rupa dua dimensi. Seperti halnya menggoreskan pensil, krayon dan sebagainya di media berupa kertas, kanvas, dan lain lain

\section{Pengertian Ilustrasi}

Fleishman mengatakan dalam seni rupa, yang dimaksud dengan ilus trasi adalah seni yang menyertai proses produksi atau pembuatan sebuah gambar, foto, atau diagram, bentuknya bisa berupa naskah tercetak, terucap, atau bahkan dalam Fleishman mengatakan dalams senirupa, yang dimaksud deng an ilus trasi adalah 
seni yang menyertai proses produksi atau pembuatan sebuah gambar, foto, atau diagram, bentuknya bisa berupa naskah tercetak, terucap, atau bahkan dalam bentuk elektronik. (Maharsi, 2004:3).

Lebih lanjut, ilus trasi adalah seni gambaryang dipakai untuk memberi penjelasan atau suatu tujuan atau maksud tertentu secara visual. (Kusrianto, 2007:140).

Berdas arkan uraian di atas dapat dis impulkan ilustrasi adalah media penyampaian pesan yang memiliki nilai tertentu.. Gambar ilustrasi yang baik harus dapat menggambarkan dengan jelas pesan/hal yang ingin disampaikan atau dijelaskan. Dari pengertian ini ilustrasi kemudian diartikan sebagai sesuatu yang membuat jelas dan terang. Ilustrasi mempunyai beberapa elemen yang dapat dijadikan sebagai objek dalam menggambar, yaitu: Gambar tentang kebudayaan daerah, seperti gambar tradisi kebudayaan Nias, Sumatera Utara (Hombo Batu/ lompat Batu).

\section{Menggambar Hombo Batu Nias}

Hombo Batu terdiri dari suku kata dalam bahasa Nias, ragam bahasa Nias Selatan. Kata hombo merupakan kata yang tidak dapat berdiri sendiri apabila tidak ada imbuhan (misalnya hoboi, fahombo atau humobo) atau kata yang mengikuti (misalnya hombo-batu) Hal ini s ama dengan katalayang. Kata y ang tidak dapat berdin sendiri tanpa imbuhan atau kata yang mengikutinya. (Zagoto, dalam Kamus Nias Indonesia 2010:90).

Fahombo, Hombo Batu atau dalam bahasa Indonesia (Lompat Batu) adalah olahraga tradisional suku Nias. Olahraga yang sebelumnya merupakan rutual pendewasaan suku Nias inibanyak dilakukan diPulau Nias dan menjadi objek wis ata tradisional unik yang teraneh hingga ke seluruh dunia. Mereka harus
Gorga : Jurnal Seni Rupa

Volume 09 Nomor 01 Januari-Juni 2020

p-ISSN: 2301-5942 | e-ISSN: 2580-2380

melompati susunan bangunan setinggi 2 meter dengan ketebalan $40 \mathrm{~cm}$. (Ensiklopedi Wikipedia, 24/08/2019).

\section{Langkah-Langkah Menggambar Ilustrasi Hombo Batu Nias}

Sketsa merupakan gambar atau lukisan pendahuluan yang kasar ringan, semata-mata garis besar atau yang belum selesai. Sketsa akan digunakan sebagai dasar untuk menggambar ilustrasi hombo batu Nias.

Mengarsir. Kegiatan ini akan menghasilkan bentuk objek yang terlihat jelas. Mengarsir berarti menampilkan gelap terang pada objek. Teknik ini s angat perlu dalammengg ambar dengan pensil, karena dengan menggambar memakai alat pensil tidak menggunakan pensil warna, hanya menggunakan arsiran untuk menunjukkan bentuk, karakter, tekstur, dan kedalaman objek.

Setelah menyelesaikan tahap kedua langkah berikutnya adalah finishing touch Pada tahap ini yang perlu diperhatikan adalah lingkungan objek gambar yang disebut background (latar belakang). Setelah objek utama dikerjakan secara cermat maka latar belakang harus dikerjakan dengan cermat agar mendukung penampilan objek utama dan selanjutnya dapat dibingkai. Tujuan dari pada penyelesaian gambar ini adalah agar karya siswa tersebut siap untuk dinikmati ataupun dipajang.

\section{METODE PENELITIAN}

Metode yang digunakan dalam penelitian ini adalah deskriptif kualitatif. Teknik pengumpulan data yang digunakan observasi, wawancara dan dokumentasi. Instrumen peneltian yang dig unkan yaitu buku catatan, kamera dan daftar pertanyaan. Teknik analisis data yang digunakan yaitu des kriptif kualitatif.

\section{HASIL DAN PEMBAHASAN}

1.Hasil

\begin{tabular}{|c|c|c|c|c|}
\hline No & Karya & Komposisi & Proporsi & $\begin{array}{c}\text { Gelap } \\
\text { Terang }\end{array}$ \\
\hline 1 & & $\begin{array}{l}\text { Nilai rata } \\
\text { rata }=78 \\
\text { Kategori } \\
\text { cukup baik } \\
\text { (C) }\end{array}$ & $\begin{array}{l}\text { Nilai rata- } \\
\text { rata }=78 \\
\text { Kategori } \\
\text { cukup baik } \\
\text { (C) }\end{array}$ & $\begin{array}{l}\text { Nilai rata- } \\
\text { rata }=80 \\
\text { Kategori } \\
\text { cukup baik } \\
\text { (C) }\end{array}$ \\
\hline 2 & & $\begin{array}{l}\text { Nilai rata } \\
\text { rata }=83 \\
\text { Kategori } \\
\text { cukup baik } \\
\text { (C) }\end{array}$ & $\begin{array}{l}\text { Nilai rata- } \\
\text { rata }=83 \\
\text { Kategori } \\
\text { cukup baik } \\
\text { (C) }\end{array}$ & $\begin{array}{l}\text { Nilai rata- } \\
\text { rata }=85 \\
\text { Kategori } \\
\text { baik }(B)\end{array}$ \\
\hline
\end{tabular}




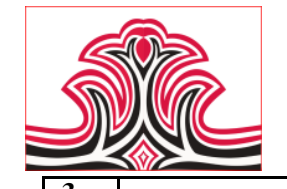

Gorga : Jurnal Seni Rupa

Volume 09 Nomor 01 Januari-Juni 2020 p-ISSN: 2301-5942 | e-ISSN: 2580-2380

\begin{tabular}{|c|c|c|c|c|}
\hline 3 & & $\begin{array}{l}\text { Nilai rata } \\
\text { rata }=78 \\
\text { Kategori } \\
\text { cukup baik } \\
\text { (C) }\end{array}$ & $\begin{array}{l}\text { Nilai rata- } \\
\text { rata }=77 \\
\text { Kategori } \\
\text { cukup baik } \\
\text { (C) }\end{array}$ & $\begin{array}{l}\text { Nilai rata- } \\
\text { rata }=80 \\
\text { Kategori } \\
\text { cukup baik } \\
\text { (C) }\end{array}$ \\
\hline 4 & & $\begin{array}{l}\text { Nilai rata } \\
\text { rata }=79 \\
\text { Kategori } \\
\text { cukup baik } \\
\text { (C) }\end{array}$ & $\begin{array}{l}\text { Nilai rata- } \\
\text { rata }=78 \\
\text { Kategori } \\
\text { cukup baik } \\
\text { (C) }\end{array}$ & $\begin{array}{l}\text { Nilai rata- } \\
\text { rata }=83 \\
\text { Kategori } \\
\text { cukup baik } \\
\text { (C) }\end{array}$ \\
\hline 5 & & $\begin{array}{l}\text { Nilai rata } \\
\text { rata }=75 \\
\text { Kategori } \\
\text { cukup baik } \\
\text { (C) }\end{array}$ & $\begin{array}{l}\text { Nilai rata- } \\
\text { rata }=75 \\
\text { Kategori } \\
\text { cukup baik } \\
\text { (C) }\end{array}$ & $\begin{array}{l}\text { Nilai rata- } \\
\text { rata }=79 \\
\text { kategori } \\
\text { cukup baik } \\
\text { (C) }\end{array}$ \\
\hline 6 & & $\begin{array}{l}\text { Nilai rata } \\
\text { rata= } 79 \\
\text { Kategori } \\
\text { cukup baik } \\
\text { (C) }\end{array}$ & $\begin{array}{l}\text { Nilai rata- } \\
\text { rata }=80 \\
\text { Kategori } \\
\text { cukup baik } \\
\text { (C) }\end{array}$ & $\begin{array}{l}\text { Nilai rata- } \\
\text { rata }=83 \\
\text { Kategori } \\
\text { cukup baik } \\
\text { (C) }\end{array}$ \\
\hline 7 & & $\begin{array}{l}\text { Nilai rata } \\
\text { rata }=77 \\
\text { Kategori } \\
\text { cukup baik } \\
\text { (C) }\end{array}$ & $\begin{array}{l}\text { Nilai rata- } \\
\text { rata }=76 \\
\text { Kategori } \\
\text { cukup baik } \\
\text { (C) }\end{array}$ & $\begin{array}{l}\text { Nilai rata- } \\
\text { rata }=79 \\
\text { Kategori } \\
\text { cukup baik } \\
\text { (C) }\end{array}$ \\
\hline 8 & & $\begin{array}{l}\text { Nilai rata } \\
\text { rata }=81 \\
\text { Kategori } \\
\text { cukup baik } \\
\text { (C) }\end{array}$ & $\begin{array}{l}\text { Nilai rata- } \\
\text { rata }=81 \\
\text { Kategori } \\
\text { cukup baik } \\
\text { (C) }\end{array}$ & $\begin{array}{l}\text { Nilai rata- } \\
\text { rata }=83 \\
\text { Kategori } \\
\text { cukup baik } \\
\text { (C) }\end{array}$ \\
\hline 9 & & $\begin{array}{l}\text { Nilai rata } \\
\text { rata }=80 \\
\text { Kategori } \\
\text { cukup baik } \\
\text { (C) }\end{array}$ & $\begin{array}{l}\text { Nilai rata- } \\
\text { rata }=80 \\
\text { Kategori } \\
\text { cukup baik } \\
\text { (C) }\end{array}$ & $\begin{array}{l}\text { Nilai rata- } \\
\text { rata }=87 \\
\text { Kategori } \\
\text { baik (B) }\end{array}$ \\
\hline 10 & & $\begin{array}{l}\text { Nilai rata } \\
\text { rata }=78 \\
\text { Kategori } \\
\text { cukup baik } \\
\text { (C) }\end{array}$ & $\begin{array}{l}\text { Nilai rata- } \\
\text { rata }=78 \\
\text { Kategori } \\
\text { cukup baik } \\
\text { (C) }\end{array}$ & $\begin{array}{l}\text { Nilai rata- } \\
\text { rata }=81 \\
\text { Kategori } \\
\text { cukup baik } \\
\text { (C) }\end{array}$ \\
\hline
\end{tabular}

\begin{tabular}{|c|c|c|c|c|}
\hline 11 & & $\begin{array}{l}\text { Nilai rata } \\
\text { rata }=75 \\
\text { Kategori } \\
\text { cukup baik } \\
\text { (C) }\end{array}$ & $\begin{array}{l}\text { Nilai rata- } \\
\text { rata = 76 } \\
\text { Kategori } \\
\text { cukup baik } \\
\text { (C) }\end{array}$ & $\begin{array}{l}\text { Nilai rata- } \\
\text { rata = } 76 \\
\text { Kategori } \\
\text { cukup baik } \\
\text { (C) }\end{array}$ \\
\hline 12 & & $\begin{array}{l}\text { Nilai rata } \\
\text { rata }=74 \\
\text { Kategori } \\
\text { kurang (D) }\end{array}$ & $\begin{array}{l}\text { Nilai rata- } \\
\text { rata }=74 \\
\text { Kategori } \\
\text { Kurang (D) }\end{array}$ & $\begin{array}{l}\text { Nilai rata- } \\
\text { rata }=74 \\
\text { Kategori } \\
\text { Kurang (D) }\end{array}$ \\
\hline 13 & & $\begin{array}{l}\text { Nilai rata } \\
\text { rata }=81 \\
\text { Kategori } \\
\text { cukup baik } \\
\text { (C) }\end{array}$ & $\begin{array}{l}\text { Nilai rata- } \\
\text { rata }=82 \\
\text { Kategori } \\
\text { cukup baik } \\
\text { (C) }\end{array}$ & $\begin{array}{l}\text { Nilai rata- } \\
\text { rata }=81 \\
\text { Kategori } \\
\text { cukup baik } \\
\text { (C) }\end{array}$ \\
\hline 14 & & $\begin{array}{l}\text { Nilai rata } \\
\text { rata }=82 \\
\text { Kategori } \\
\text { cukup baik } \\
\text { (C) }\end{array}$ & $\begin{array}{l}\text { nilai rata- } \\
\text { rata }=81 \\
\text { Kategori } \\
\text { cukup baik } \\
\text { (C) }\end{array}$ & $\begin{array}{l}\text { Nilai rata- } \\
\text { rata }=84 \\
\text { Kategori } \\
\text { baik (B) }\end{array}$ \\
\hline 15 & & $\begin{array}{l}\text { Nilai rata } \\
\text { rata }=79 \\
\text { Kategori } \\
\text { cukup baik } \\
\text { (C) }\end{array}$ & $\begin{array}{l}\text { Nilai rata- } \\
\text { rata }=79 \\
\text { Kategori } \\
\text { cukup baik } \\
\text { (C) }\end{array}$ & $\begin{array}{l}\text { Nilai rata- } \\
\text { rata }=76 \\
\text { Kategori } \\
\text { cukup baik } \\
\text { (C) }\end{array}$ \\
\hline 16 & & $\begin{array}{l}\text { Nilai rata } \\
\text { rata }=79 \\
\text { Kategori } \\
\text { cukup baik } \\
\text { (C) }\end{array}$ & $\begin{array}{l}\text { Nilai rata- } \\
\text { rata }=78 \\
\text { Kategori } \\
\text { cukup baik } \\
\text { (C) }\end{array}$ & $\begin{array}{l}\text { Nilai rata- } \\
\text { rata = 79 } \\
\text { Kategori } \\
\text { cukup baik } \\
\text { (C) }\end{array}$ \\
\hline 17 & & $\begin{array}{l}\text { Nilai rata } \\
\text { rata }=81 \\
\text { Kategori } \\
\text { cukup baik } \\
\text { (C) }\end{array}$ & $\begin{array}{l}\text { Nilai rata- } \\
\text { rata }=78 \\
\text { Kategori } \\
\text { cukup baik } \\
\text { (C) }\end{array}$ & $\begin{array}{l}\text { Nilai rata- } \\
\text { rata }=82 \\
\text { Kategori } \\
\text { cukup baik } \\
\text { (C) }\end{array}$ \\
\hline 18 & & $\begin{array}{l}\text { Nilai rata } \\
\text { rata }=80 \\
\text { Kategori } \\
\text { cukup baik } \\
\text { (C) }\end{array}$ & $\begin{array}{l}\text { Nilai rata- } \\
\text { rata }=78 \\
\text { Kategori } \\
\text { cukup baik } \\
\text { (C) }\end{array}$ & $\begin{array}{l}\text { Nilai rata- } \\
\text { rata }=76 \\
\text { Kategori } \\
\text { cukup baik } \\
\text { (C) }\end{array}$ \\
\hline 19 & & $\begin{array}{l}\text { Nilai rata } \\
\text { rata }=79 \\
\text { Kategori } \\
\text { cukup baik } \\
\text { (C) }\end{array}$ & $\begin{array}{l}\text { Nilai rata- } \\
\text { rata }=77 \\
\text { Kategori } \\
\text { cukup baik } \\
\text { (C) }\end{array}$ & $\begin{array}{l}\text { Nilai rata- } \\
\text { rata }=75 \\
\text { Kategori } \\
\text { cukup baik } \\
\text { (C) }\end{array}$ \\
\hline
\end{tabular}




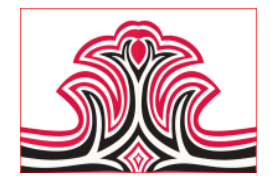

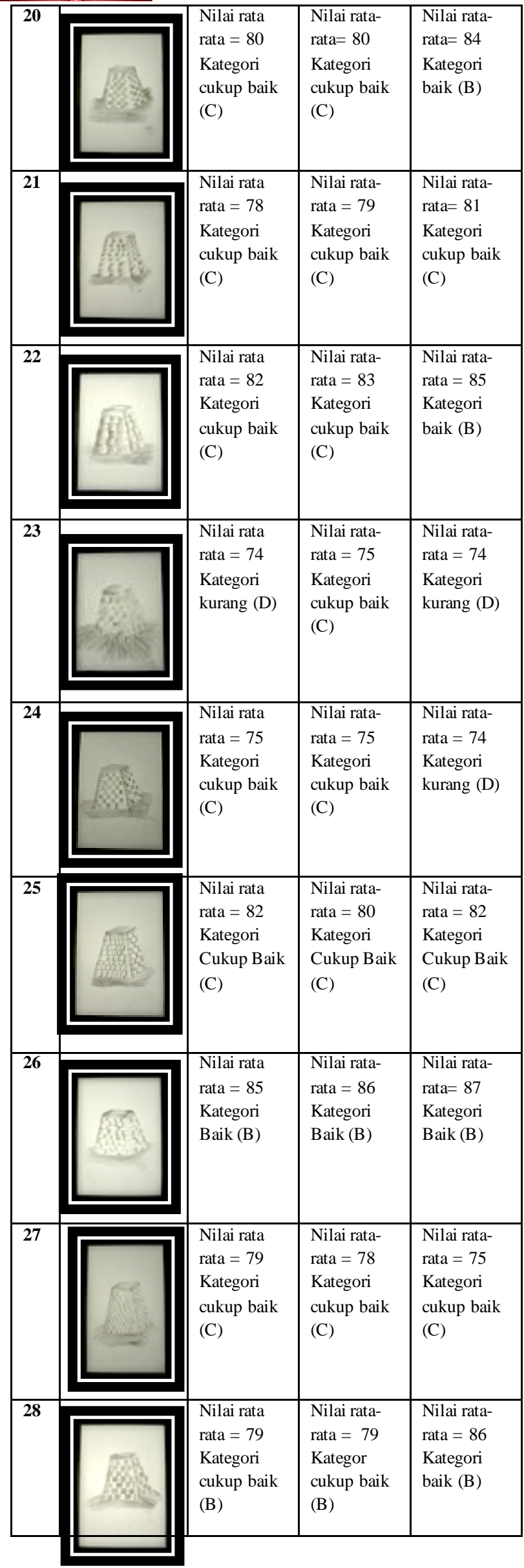

Gorga : Jurnal Seni Rupa

Volume 09 Nomor 01 Januari-Juni 2020 p-ISSN: 2301-5942 | e-ISSN: 2580-2380

\begin{tabular}{|l|l|l|l|l|}
\hline 29 & $\begin{array}{l}\text { Nilai rata } \\
\text { rata }=78\end{array}$ & $\begin{array}{l}\text { Nilai rata- } \\
\text { rata }=78\end{array}$ & $\begin{array}{l}\text { Nilai rata- } \\
\text { rata }=75\end{array}$ \\
& Kategori \\
cukup baik & $\begin{array}{l}\text { Kategori } \\
\text { cukup baik } \\
\text { (C) }\end{array}$ & Kategori \\
(C) & & \\
& & & \\
& & & \\
\hline
\end{tabular}

\section{Pembahasan}

1). Karya 1

Indikator komposisi yang di analis is deng an nilai rata rata $=78$ kategori (cukup) yaitu tata letak objek ditengah-tengah bidang gambar sudah cukup baik (C), objek gambar tidak terlalu kecil atau terlalu besar jika dibandingkan dengan bidang gambar atau kertas.

Indikator penilaian berikutnya adalah proporsi y ang di analisis dengan nilai rata-rata $=78$ kategori cukup baik (C), yaitu objek yang digambar sudah hampir sesuai dengan bentuk proporsi pada objek yang dig ambarkan.

Selanjutnya pada indikator yang terakhir yaitu gelapterang yang di analisis dengan nilai rata-rata $=80$ kategori cukup baik (C), yaitu menghasilkan gelap terang dan dimensi dalam menggambar dan sudah menerapkan teknik arsir dengan alat pensil yang baik, sehingga menghasilkan karya yang sangat mirip dengan objek yang sebenarnya.

\section{2). Karya 2}

Indikator komposisi yang di analisis deng an nilai rata rata $=83$ kategori (cukup) yaitu tata letak objek ditengah-tengah bidang gambar sudah cukup baik (C), objek gambar tidak terlalu kecil atau terlalu besar jika dibandingkan dengan bidang gambar atau kertas. Indikator penilaian berikutny a adalah proporsi y ang di analisis dengan nilai rata-rata $=83$ kategori cukup baik (C), yaitu objek yang digambar sudah hampir sesuai dengan bentuk proporsi pada objek y ang digambarkan.

Selanjutnya pada indikator yang terakhir yaitu gelapterang yang di analisis dengan nilai rata-rata $=85$ kategori baik (B), yaitu gelap-terang menghasilkan dimensi dalam menggambar sehingga menghasilkan karya yang mendekati mirip dengan objek yang sebenarnya. Selain itu penerapan teknik arsiran dalam hal gelap terang cukup bagus dalam menggambar ilustrasi hombo batu.

\section{3). Karya 3}

Indikator komposisi yang di analis is deng an nilai rata rata $=78$ kategori (cukup) yaitu tata letak objek diteng ah-tengah bidang gambar sudah cukup baik (C), objek gambar tidak terlalu kecil atau terlalu besar jika dibandingkan dengan bidang gambar atau kertas. 
Indikator penilaian berikutnya adalah proporsi yang di analis is dengan nilai rata-rata $=77$ kategori cukup baik (C), yaitu objek yang digambar sudah hampir sesuai dengan bentuk proporsi pada objek yang digambarkan.

Selanjutnya pada indikator yang terakhir yaitu gelapterang yang di analisis dengan nilai rata-rata $=80$ kategori cukup baik (C), yaitu menghasilkan gelap terang dan dimensi dalam menggambar dan sudah menerapkan teknik ars ir dengan alat pensil yang baik, sehingga menghasilkan karya yang sangat mirip dengan objek yang sebenarnya.

\section{4). Karya 4}

Indikator komposisi yang di analisis dengan nilai rata rata $=79$ kategori (cukup) yaitu tata letak objek ditengah-tengah bidang gambar sudah cukup baik (C), objek gambar tidak terlalu kecil atau terlalu besar jika dibandingkan dengan bidang gambar atau kertas.

Indikator penilaian berikutnya adalah proporsi yang di analis is dengan nilai rata-rata $=78$ kategoricukup baik (C), yaitu objek yang digambar sudah hampir sesuai dengan bentuk proporsi pada objek yang digambarkan.

Selanjutnya pada indikator yang terakhir yaitu gelapterang yang di analis is dengan nilai rata-rata $=83$ kategori cukup baik (C), yaitu menghasilkan gelap terang dan dimensi dalam menggambar dan sudah menerapkan teknik ars ir dengan alat pensil yang baik, sehingga menghasilkan karya yang sangat mirip dengan objek yang sebenarnya.

\section{5). Karya 5}

Indikator komposisi yang di analisis dengan nilai rata rata $=75$ kategori (cukup) yaitu tata letak objek ditengah-tengah bidang gambar sudah cukup baik(C), objek gambar tidak terlalu kecil atau terlalu besar jika dibandingkan dengan bidang gambar atau kertas.

Indikator penilaian berikutnya adalah proporsi yang di analis is dengan nilai rata-rata $=75$ kategori cukup baik (C), yaitu objek yang digambar sudah hampir sesuai dengan bentuk proporsi pada objek yang digambarkan.

Selanjutnya pada indikator yang terakhir yaitu gelapterang yang di analisis dengan nilai rata-rata= 79 kategori cukup baik (C), yaitu menghasilkan gelap terang dan dimensi dalam menggambar dan sudah menerapkan teknik ars ir dengan alat pensil yang baik, sehingga menghasilkan karya yang sangat mirip dengan objek yang sebenarnya.

\section{6). Karya 6}

Indikator komposisi yang di analis is dengan nilai rata rata $=79$ kategori (cukup) yaitu tata letak objek ditengah-tengah bidang gambar sudah cukup baik(C), objek gambar tidak terlalu kecil atau terlalu besar jika dibandingkan dengan bidang gambar atau kertas.

Indikator penilaian berikutnya adalah proporsi yang di analisis den gan nilai rata-rata $=80$ kategori cukup baik (C), yaitu objek yang digambar sudah hampir sesuai dengan bentuk proporsi pada objek yang digambarkan.

Selanjutnya pada indikator yang terakhir yaitu gelapterang yang di analisis dengan nilai rata-rata $=83$ kategori cukup baik (C), yaitu menghasilkan gelap terang dan dimensi dalam menggambar dan sudah menerapkan teknik arsir dengan alat pensil yang baik, sehingga menghasilkan karya yang sangat mirip dengan objek yang sebenarnya.

\section{7). Karya 7}

Indikator komposisi yang di analis is deng an nilai rata rata $=77$ kategori (cukup) yaitu tata letak objek ditengah-tengah bidang gambar sudah cukup baik(C), objek gambar tidak terlalu kecil atau terlalu besar jika dibandingkan dengan bidang gambar atau kertas.

Indikator penilaian berikutny a adalah proporsi y ang di analisis dengan nilai rata-rata $=76$ kategori cukup baik (C), yaitu objek yang digambar sudah hampir sesuai dengan bentuk proporsi pada objek yang dig ambarkan.

Selanjutnya pada indikator yang terakhir yaitu gelapterang yang di analisis dengan nilai rata-rata $=79$ kategori cukup baik (C), yaitu menghasilkan gelap terang dan dimensi dalam menggambar dan sudah menerapkan teknik arsir dengan alat pensil yang baik, sehingga menghasilkan karya yang sangat mirip dengan objek yang sebenarnya.

\section{8). Karya 8}

Indikator komposisi yang di analis is deng an nilai rata rata $=81$ kategori (cukup) yaitu tata letak objek ditengah-tengah bidang gambar sudah cukup baik (C), objek gambar tidak terlalu kecil atau terlalu besar jika dibandingkan dengan bidang gambar atau kertas.

Indikator penilaian berikutnya adalah proporsi yang di analisis dengan nilai rata-rata $=81$ kategori cukup baik (C), yaitu objek yang digambar sudah hampir sesuai dengan bentuk proporsi pada objek yang digambarkan.

Selanjutnya pada indikator yang terakhir yaitu gelapterang yang di analisis dengan nilai rata-rata $=83$ 
kategori cukup baik (C), yaitu menghasilkan gelap terang dan dimensi dalam menggambar dan sudah menerapkan teknik arsir dengan alat pensil yang baik, sehingga menghasilkan karya yang sangat mirip dengan objek yang sebenarnya.

\section{9). Karya 9}

Indikator komposisi yang di analisis deng an nilai rata rata $=80$ kategori (cukup) yaitu tata letak objek ditengah-tengah bidang gambar sudah cukup baik (C), objek gambar tidak terlalu kecil atau terlalu besar jika dibandingkan dengan bidang gambar atau kertas.

Indikator penilaian berikutnya adalah proporsi yang di analis is dengan nilai rata-rata $=80$ kategoricukup baik (C), yaitu objek yang digambar sudah hampir sesuai dengan bentuk proporsi pada objek yang digambarkan.

Selanjutnya pada indikator yang terakhir yaitu gelapterang yang di analisis dengan nilai rata-rata $=87$ kategori baik (B), yaitu gelap-terang menghasikan dimensi dalam menggambar sehingga menghasilkan karya yang mendekati mirip dengan objek yang sebenarnya. Selain itu penerapan teknik arsiran dalam hal gelap terang cukup bagus dalam menggambar ilustrasi hombo batu.

\section{0). Karya 10}

Indikator komposisi yang di analisis dengan nilai rata rata $=78$ kategori (cukup) yaitu tata letak objek ditengah-tengah bidang gambar sudah cukup baik (C), objek gambar tidak terlalu kecil atau terlalu besar jika dibandingkan dengan bidang gambar atau kertas.

Indikator penilaian berikutnya adalah proporsi yang di analis is dengan nilai rata-rata $=78$ kategoricukup baik (C), yaitu objek yang digambar sudah hampir sesuai dengan bentuk proporsi pada objek yang dig ambarkan.

Selanjutnya pada indikator yang terakhir yaitu gelapterang yang di analisis dengan nilai rata-rata $=81$ kategori cukup baik (C), yaitu menghasilkan gelap terang dan dimensi dalam menggambar dan sudah menerapkan teknik arsir dengan alat pensil yang baik, sehingga menghasilkan karya yang sangat mirip dengan objek yang sebenarnya.

\section{1). Karya 11}

Indikator komposisi yang di analisis dengan nilai rata rata $=75$ kategori (cukup) yaitu tata letak objek ditengah-tengah bidang gambar sudah cukup baik (C), objek gambar tidak terlalu kecil atau terlalu besar jika dibandingkan dengan bidang gambar atau kertas.
Gorga : Jurnal Seni Rupa

Volume 09 Nomor 01 Januari-Juni 2020

p-ISSN: 2301-5942 | e-ISSN: 2580-2380

Indikator penilaian berikutnya adalah proporsi y ang di analisis dengan nilai rata-rata $=76$ kategori cukup baik (C), yaitu objek yang digambar sudah hampir sesuai dengan bentuk proporsi pada objek yang dig ambarkan.

Selanjutnya pada indikator yang terakhir yaitu gelapterang yang di analisis dengan nilai rata-rata $=76$ kategori cukup baik (C), yaitu menghasilkan gelap terang dan dimensi dalam menggambar dan sudah menerapkan teknik arsir dengan alat pensil yang baik, sehingga menghasilkan karya yang sangat mirip dengan objek yang sebenarnya.

\section{2). Karya 12}

Indikator komposisi yang dianalisis dengan nilai rata rata $=74$ kategori (kurang), yaitu mampu menyu suntata letak objek ditengah-tengah pada posisi kertas (bidang gambar). Selain itu pemilihan objek juga sudah cukup baik.

Indikator penilaian berikutnya adalah proporsi yang dianalis is dengan nilai rata-rata $=74$ kategori (kurang), yaitu objek yang digambar masih kurang mendekati dengan proporsi objek yang sebenarnya.

Selanjutnya pada indikator yang terakhir yaitu gelapterang yang di analisis dengan nilai rata-rata $=74$ dengan kategori (kurang), y aitu belum memperlihatkan kesan gelap terang dalam menggambar.

\section{3). Karya 13}

Indikator komposisi yang di analisis deng an nilai rata rata $=81$ kategori (cukup) yaitu tata letak objek ditengah-tengah bidang gambar sudah cukup baik (C), objek gambar tidak terlalu kecil atau terlalu besar jika dibandingkan dengan bidang gambar atau kertas.

Indikator penilaian berikutnya adalah proporsi y ang di analisis dengan nilai rata-rata $=82$ kategori cukup baik (C), yaitu objek yang digambar sudah hampir sesuai dengan bentuk proporsi pada objek yang dig ambarkan.

Selanjutnya pada indikator yang terakhir yaitu gelapterang yang di analisis dengan nilai rata-rata $=81$ kategori cukup baik (C), yaitu menghasilkan gelap terang dan dimensi dalam menggambar dan sudah menerapkan teknik arsir dengan alat pensil yang baik, sehingga menghasilkan karya yang sangat mirip dengan objek yang sebenarnya.

\section{4). Karya 14}

Indikator komposisi yang di analisis deng an nilai rata rata $=82$ kategori (cukup) yaitu tata letak objek ditengah-tengah bidang gambar sudah cukup baik (C), 
objek gambar tidak terlalu kecil atau terlalu besar jika dibandingkan dengan bidang gambar atau kertas.

Indikator penilaian berikutnya adalah proporsi yang di analis is dengan nilai rata-rata $=81$ kategori cukup baik (C), yaitu objek yang digambar sudah hampir sesuai dengan bentuk proporsi pada objek yang dig ambarkan.

Selanjutnya pada indikator yang terakhir yaitu gelapterang yang di analisis dengan nilai rata-rata $=84$ kategori baik (B), yaitu gelap-terang menghasilkan dimensi dalam menggambar sehingga menghasilkan karya yang mendekati mirip dengan objek yang sebenarnya. Selain itu penerapan teknik arsiran dalam hal gelap terang cukup bagus dalam menggambar ilustrasi hombo batu.

\section{Karya 15}

Indikator komposisi yang di analisis dengan nilai rata rata $=79$ kategori (cukup) yaitu tata letak objek ditengah-tengah bidang gambar sudah cukup baik (C), objek gambar tidak terlalu kecil atau terlalu besar jika dibandingkan dengan bidang gambar atau kertas.

Indikator penilaian berikutnya adalah proporsi yang di analis is dengan nilai rata-rata $=79$ kategori cukup baik (C), yaitu objek yang digambar sudah hampir sesuai dengan bentuk proporsi pada objek yang digambarkan.

Selanjutnya pada indikator yang terakhir yaitu gelapterang yang di analisis dengan nilai rata-rata $=76$ kategori cukup baik (C), yaitu menghasilkan gelap terang dan dimensi dalam menggambar dan sudah menerapkan teknik arsir dengan alat pensil yang baik, sehingga menghasilkan karya yang sangat mirip dengan objek yang sebenarnya.

\section{6). Karya 16}

Indikator komposisi yang di analisis dengan nilai rata rata $=79$ kategori (cukup) yaitu tata letak objek ditengah-tengah bidang gambar sudah cukup baik (C), objek gambar tidak terlalu kecil atau terlalu besar jika dibandingkan dengan bidang gambar atau kertas.

Indikator penilaian berikutnya adalah proporsi yang di analis is dengan nilai rata-rata $=78$ kategori cukup baik (C), yaitu objek yang digambar sudah hampir sesuai dengan bentuk proporsi pada objek yang digambarkan.

Selanjutnya pada indikator yang terakhir yaitu gelapterang yang di analisis dengan nilai rata-rata $=79$ kategori cukup baik (C), yaitu menghasilkan gelap terang dan dimensi dalam menggambar dan sudah menerapkan teknik arsir dengan alat pensil yang baik,
Gorga : Jurnal Seni Rupa

Volume 09 Nomor 01 Januari-Juni 2020

p-ISSN: 2301-5942 | e-ISSN: 2580-2380

sehingga menghasilkan karya yang sangat mirip dengan objek yang sebenarnya.

\section{7). Karya 17}

Indikator komposisi yang di analis is deng an nilai rata rata $=81$ kategori (cukup) yaitu tata letak objek ditengah-tengah bidang gambar sudah cukup baik (C), objek gambar tidak terlalu kecil atau terlalu besar jika dibandingkan dengan bidang gambar atau kertas.

Indikator penilaian berikutnya adalah proporsi y ang di analisis dengan nilai rata-rata $=78$ kategori cukup baik (C), yaitu objek yang digambar sudah hampir sesuai dengan bentuk proporsi pada objek yang dig ambarkan.

Selanjutnya pada indikator yang terakhir yaitu gelapterang yang di analis is dengan nilai rata-rata $=82$ kategori cukup baik (C), yaitu menghasilkan gelap terang dan dimensi dalam menggambar dan sudah menerapkan teknik arsir dengan alat pensil yang baik, sehingga menghasilkan karya yang sangat mirip dengan objek yang sebenarnya.

\section{8). Karya 18}

Indikator komposisi yang di analis is deng an nilai rata rata $=80$ kategori (cukup) yaitu tata letak objek ditengah-tengah bidang gambar sudah cukup baik (C), objek gambar tidak terlalu kecil atau terlalu besar jika dibandingkan dengan bidang gambar atau kertas.

Indikator penilaian berikutny a adalah proporsi y ang di analisis den gan nilai rata-rata $=78$ kategori cukup baik (C), yaitu objek yang digambar sudah hampir sesuai dengan bentuk proporsi pada objek yang digambarkan.

Selanjutnya pada indikator yang terakhir yaitu gelapterang yang di analisis dengan nilai rata-rata $=76$ kategori cukup baik (C), yaitu menghasilkan gelap terang dan dimensi dalam menggambar dan sudah menerapkan teknik ars ir dengan alat pensil y ang baik, sehingga menghasilkan karya yang sangat mirip dengan objek yang sebenarnya.

\section{9). Karya 19}

Indikator komposisi yang di analis is dengan nilai rata rata $=79$ kategori (cukup) yaitu tata letak objek ditengah-tengah bidang gambar sudah cukup baik (C), objek gambar tidak terlalu kecil atau terlalu besar jika dibandingkan dengan bidang gambar atau kertas.

Indikator penilaian berikutnya adalah proporsi y ang di analisis dengan nilai rata-rata $=77$ kategoricukup baik (C), yaitu objek yang digambar sudah hampir sesuai dengan bentuk proporsi pada objek yang digambarkan. 
Selanjutnya pada indikator yang terakhir yaitu gelapterang yang di analisis dengan nilai rata-rata $=75$ kategori cukup baik (C), yaitu menghasilkan gelap terang dan dimensi dalam menggambar dan sudah menerapkan teknik arsir dengan alat pensil yang baik, sehingga menghasilkan karya yang sangat mirip dengan objek yang sebenarnya.

\section{0). Karya 20}

Indikator komposisi yang di analisis dengan nilai rata rata $=80$ kategori (cukup) yaitu tata letak objek ditengah-tengah bidang gambar sudah cukup baik (C), objek gambar tidak terlalu kecil atau terlalu besar jika dibandingkan dengan bidang gambar atau kertas.

Indikator penilaian berikutnya adalah proporsi yang di analis is dengan nilai rata-rata $=80$ kategori cukup baik (C), yaitu objek yang digambar sudah hampir sesuai dengan bentuk proporsi pada objek yang digambarkan.

Selanjutnya pada indikator yang terakhir yaitu gelapterang yang di analisis dengan nilai rata-rata $=84$ kategori baik (B), yaitu gelap-terang menghasilkan dimensi dalam menggambar sehingga menghasilkan karya yang mendekati mirip dengan objek yang sebenarnya. Selain itu penerapan teknik ars iran dalam hal gelap terang cukup bagus dalam menggambar ilus trasi hombo batu.

\section{1). Karya 21}

Indikator komposisi yang di analisis dengan nilai rata rata $=78$ kategori (cukup) yaitu tata letak objek ditengah-tengah bidang gambar sudah cukup baik (C), objek gambar tidak terlalu kecil atau terlalu besar jika dibandingkan dengan bidang gambar atau kertas.

Indikator penilaian berikutny a adalah proporsi yang di analis is dengan nilai rata-rata $=79$ kategori cukup baik (C), yaitu objek yang digambar sudah hampir sesuai dengan bentuk proporsi pada objek yang digambarkan.

Selanjutnya pada indikator yang terakhir yaitu gelapterang yang di analisis dengan nilai rata-rata $=81$ kategori cukup baik (C), yaitu menghasilkan gelap terang dan dimensi dalam menggambar dan sudah menerapkan teknik ars ir dengan alat pensil yang baik, sehingga menghasilkan karya yang sangat mirip dengan objek yang sebenarnya.

\section{2). Karya 22}

Indikator komposisi yang di analisis dengan nilai rata rata $=82$ kategori (cukup) yaitu tata letak objek ditengah-tengah bidang gambar sudah cukup baik (C),
Gorga : Jurnal Seni Rupa

Volume 09 Nomor 01 Januari-Juni 2020

p-ISSN: 2301-5942 | e-ISSN: 2580-2380

objek gambar tidak terlalu kecil atau terlalu besar jika dibandingkan dengan bidang gambar atau kertas.

Indikator penilaian berikutny a adalah proporsi y ang di analisis dengan nilai rata-rata $=80$ kategori cukup baik (C), yaitu objek yang digambar sudah hampir sesuai dengan bentuk proporsi pada objek yang digambarkan.

Selanjutnya pada indikator yang terakhir yaitu gelapterang yang di analisis dengan nilai rata-rata $=82$ kategori cukup baik (C), yaitu menghasilkan gelap terang dan dimensi dalam menggambar dan sudah menerapkan teknik ars ir dengan alat pensil yang baik, sehingga menghasilkan karya yang sangat mirip dengan objek yang sebenarnya.

\section{3). Karya 23}

Indikator komposisi yang dianalis is dengan nilai rata rata $=85$ kategori baik (B), yaitu mampu memperkirakan tata letak ditengah-tengah bidang gambar, selain itu objek gambar tidak terlalu kecil atau terlalu besarjika dibandingkan gambar dan keselarasan antara objek dan kertas.

Indikator penilaian berikutnya adalah proporsi yang dianalis is dengan nilai rata-rata $=85$ dengan kategon baik (B), yaitu objek yang dig ambar tidak mengalami distorsi ataupun pada karya Rizki Nasution perbandingan ukuran objek gambar yang satu dengan objek gambar lainnya tampak wajar.

Selanjutnya pada indikator yang terakhir yaitu gelapterang yang di analisis dengan nilai rata-rata $=87$ kategori baik (B), yaitu gelap-terang menghasilkan dimensi dalam menggambar sehingga menghasilkan karya yang mendekati mirip dengan objek yang sebenarnya. Selain itu penerapan teknik arsiran dalam hal gelap terang cukup bagus dalam menggambar ilustrasi hombo batu.

\section{4). Karya 24}

Indikator komposisi yang di analis is deng an nilai rata rata $=79$ kategori (cukup) yaitu tata letak objek ditengah-tengah bidang gambar sudah cukup baik(C), objek gambar tidak terlalu kecil atau terlalu besar jika dibandingkan dengan bidang gambar atau kertas.

Indikator penilaian berikutnya adalah proporsi yang di analisis dengan nilai rata-rata $=78$ kategoricukup baik (C), yaitu objek yang digambar sudah hampir sesuai dengan bentuk proporsi pada objek yang dig ambarkan.

Selanjutnya pada indikator yang terakhir yaitu gelapterang yang di analisis dengan nilai rata-rata $=75$ 
kategori cukup baik (C), yaitu menghasilkan gelap terang dan dimensi dalam menggambar dan sudah menerapkan teknik arsir dengan alat pensil yang baik, sehingga menghasilkan karya yang sangat mirip dengan objek yang sebenarnya.

\section{5). Karya 25}

Indikator komposisi yang di analisis dengan nilai rata rata $=79$ kategori (cukup) yaitu tata letak objek ditengah-tengah bidang gambar sudah cukup baik (C), objek gambar tidak terlalu kecil atau terlalu besar jika dibandingkan dengan bidang gambar atau kertas.

Indikator penilaian berikutnya adalah proporsi yang di analis is dengan nilai rata-rata $=79$ kategori cukup baik (C), yaitu objek yang digambar sudah hampir sesuai dengan bentuk proporsi pada objek yang digambarkan.

Selanjutnya pada indikator yang terakhir yaitu gelapterang yang di analisis dengan nilai rata-rata $=80$ kategori cukup baik (C), yaitu menghasilkan gelap terang dan dimensi dalam menggambar dan sudah menerapkan teknik arsir dengan alat pensil yang baik, sehingga menghasilkan karya yang sangat mirip dengan objek yang sebenarnya.

\section{6). Karya 26}

Indikator komposisi yang di analisis dengan nilai rata rata $=78$ kategori (cukup) yaitu tata letak objek ditengah-tengah bidang gambar sudah cukup baik (C), objek gambar tidak terlalu kecil atau terlalu besar jika dibandingkan dengan bidang gambar atau kertas.

Indikator penilaian berikutnya adalah proporsi yang di analis is dengan nilai rata-rata $=78$ kategoricukup baik (C), yaitu objek yang digambar sudah hampir sesuai dengan bentuk proporsi pada objek yang digambarkan.

Selanjutnya pada indikator yang terakhir yaitu gelapterang yang di analisis dengan nilai rata-rata $=75$ kategori cukup baik (C), yaitu menghasilkan gelap terang dan dimensi dalam menggambar dan sudah menerapkan teknik arsir dengan alat pensil yang baik, sehingga menghasilkan karya yang sangat mirip dengan objek yang sebenarnya.

\section{7). Karya 27}

Indikator komposisi yang di analisis dengan nilai rata rata $=82$ kategori (cukup) yaitu tata letak objek ditengah-tengah bidang gambar sudah cukup baik (C), objek gambar tidak terlalu kecil atau terlalu besar jika dibandingkan dengan bidang gambar atau kertas.
Gorga : Jurnal Seni Rupa

Volume 09 Nomor 01 Januari-Juni 2020

p-ISSN: 2301-5942 | e-ISSN: 2580-2380

Indikator penilaian berikutnya adalah proporsi y ang di analisis dengan nilai rata-rata $=83$ kategori cukup baik (C), yaitu objek yang digambar sudah hampir sesuai dengan bentuk proporsi pada objek yang dig ambarkan. Selanjutnya pada indikator yang terakhir yaitu gelapterang yang di analisis dengan nilai rata-rata $=85$ kategori baik (B), yaitu gelap-terang menghasilkan dimensi dalam menggambar sehingga menghasikan karya yang mendekati mirip dengan objek yang sebenarnya. Selain itu penerapan teknik arsiran dalam hal gelap terang cukup bagus dalam menggambar ilustrasi hombo batu.

\section{8). Karya 28}

Indikator komposisi yang dianalis is dengan nilai rata rata $=74$ kategori kurang, yaitu mampu menyusun tata letak objek ditengah-tengah pada posisi kertas (bidang gambar). Selain itu pemilihan objek jug a sudah cukup baik.

Indikator penilaian berikutnya adalah proporsi yang di analisis dengan nilai rata-rata $=75$ kategori cukup baik (C), yaitu objek yang dig ambar sudah hampir sesuai dengan bentuk proporsi pada objek yang dig ambarkan

Selanjutnya pada indikator yang terakhir yaitu gelapterang yang di analisis dengan nilai rata-rata $=74$ dengan kategori (kurang), y aitu belummemperlihatkan kesan gelap terang dalam menggambar.

\section{9). Karya 29}

Indikator komposisi yang di analisis deng an nilai rata rata $=75$ kategori (cukup) yaitu tata letak objek ditengah-tengah bidang gambar su dah cukup baik (C), objek gambar tidak terlalu kecil atau terlalu besar jika dibandingkan dengan bidang gambar atau kertas.

Indikator penilaian berikutnya adalah proporsi yang di analisis dengan nilai rata-rata $=75$ kategori cukup baik (C), yaitu objek yang digambar sudah hampir sesuai dengan bentuk proporsi pada objek yang dig ambarkan.

Selanjutnya pada indikator yang terakhir yaitu gelapterang yang di analisis dengan nilai rata-rata $=74$ dengan kategori (kurang), y aitu belummemperlihatkan kesan gelap terang dalam menggambar.

\section{KESIMPULAN DAN SARAN 1.Kesimpulan}

Berdasarkan pembahasan dan hasil penelitian di bab IV, maka dapat diketahui bahwa : Kemampuan siswa dalam mencapai indikator komposisi pada karya gambar ilustrasi hombo batu di kelas VIII-A SMP 
Negeri 1 Gunungsitoli Utara rata-rata mencapai nilai 78,9 dan termasuk dalam kategori Cukup.

Kemampuan siswa dalammencapai indikator Proporsi pada kary a gambar ilustrasi hombo batu di kelas VIIIA SMP Negeri 1 Gunungsitoli Utara rata-ratamencapai nilai 78,6 dan termasuk dalam kategori Cukup. Kemampuan siswa dalam mencapai indikator Gelapterang pada karya gambar ilus trasi hombo batu di kelas VIII-A SMP Negeri 1 Gunungsitoli Utara rata-rata mencapai nilai 79,9 dan termasuk dalam kategori Cukup.

\section{Saran}

Berdasarkan hasil penelitian, analis is dan simpulan penelitian, maka peneliti menyarankan : Kepada guru agar sebaiknya menjelaskan hal-hal faktual yang berkaitan dengan landasan-landasan teoritis yang bersifat pengetahuan sesuai dengan tujuan pembelajaran berdasarkan indikator-indikator yang digunakan. Dis arankan kepada guru agar menjelaskan hal-hal konseptual yang berkaitan dengan ciri suatu objek sehingga sis wa mampu menangkap ciri objek ters ebut. Dis arankan kepada s iswa dalammeng gambar, siswa harus mampu mengamati objek yang ada, sehingga ia bisa mengetahui dan memahami secara langsung karakteristik objek y ang akan digambarnya.

Disarankan kepadas siswa harus mampu mengenal media dan teknik yang digunakannya seperti cara menggunakan pensil dalam menggambar ilustrasi hombo batu, sehingga penguasaan tekniknya akan mampu menciptakan karya gambar ilustrasi hombo batu yang baik. Disarankan agar sekolah untuk lebih banyak membantu siswa dalam pengadaan referensi dari berbagai media informasi untuk menambah wawas an siswa dalam materi menggambar.

Dis arankan kepada sekolah hendaknya memfasilitasi ruangan khusus menggambar dan ekskul menggambar untuk menjaga minat dan mengembangkan minatminat siswa yang memiliki bakat menggambar. Sehing ga menunjang hasil nilai sis wa yang lebih baik dalam pembelajaran menggambar.

\section{DAFTAR RUJUKAN}

Aesijah, Siti. (2000). Latar Belakang Penciptaan Seni (Background of Creative Art). Jurnal Harmonia pengetahuan Dan Pemikiran Seni, 01(02), 62-74.

Apriyatno, Veri. (2013). Cepat Dan Mudah

Belajar Menggambar Dengan

Pensil. Jakarta Selatan: PT Kawan Kita.
Gorga : Jurnal Seni Rupa

Volume 09 Nomor 01 Januari-Juni 2020

p-ISSN: 2301-5942 | e-ISSN: 2580-2380

KualitatifTeori \& Paraktik. Jakarta:

Bumi Aksara.

Kusrianto, Adi. (2007). Pengantar Desain Komunikasi Visual. Yogyakarta: Andi Offset.

Maharsi, Indiria. (2016). Mudah dan Praktis Menggambar dengan Pensil Karikatur. Yogyakarta: Media Pressindo.

Siregar, N. H., Azis, A. C. K., Mesra, M., \& Mirwa, T. (2020). Analisis Gambar Bentuk Bunga Anggrek dengan Teknik Pointilis Berwarna di SMP Al-Fityan School Medan. Gorga: Jurnal Seni Rupa, 9(1), 94-99.

Sugiyono. (2014). Metode Penelitian Pendidikan (Pendekatan Kuantitatif, Kualitatif, Dan $R \& D)$. Bandung: Alfabeta.

Surajiyo. (2007), Ilmu filsafah suatu pengantar, Jakarta: Bumi Aksara.

Widyokusumo, Lintang. (2014). Teknik Arsir Dan Proses Menggambar Dengan Media Pena. Jurnal Humaniora, 05(02), 909-918.

Zagoto, Sitasi, (2010). Kamus Nias Indonesia. Teluk dalam. Nias Selatan: Yayasan Pendidikan.

Ensiklopedi Wikipedia. (2019). Fahombo. Diunduh pada 28 Agustus 2019. [Online]. di https//id.wikipedia.org/w/index.

Gunawan, Imam. (2016). Metode Penelitian 